\title{
Methylmercury induces expression of interleukin-1 $\beta$ and interleukin-19 in mice brains
}

\author{
Tsutomu Takahashi',2, Miyuki Iwai-Shimada'1, Yukina Syakushi', Min-Seok Kim¹, \\ Gi-Wook Hwang' ${ }^{1}$, Nobuhiko Miura ${ }^{3}$ and Akira Naganuma1 \\ ${ }^{1}$ Laboratory of Molecular and Biochemical Toxicology, Graduate School of Pharmaceutical Sciences, \\ Tohoku University, Aoba-ku, Sendai 980-8578, Japan \\ ${ }^{2}$ Department of Environmental Health, School of Pharmacy, Tokyo University of Pharmacy and Life Sciences, \\ 1432-1, Horinouchi, Hachioji 192-0392, Japan \\ ${ }^{3}$ Division of Health Effects Research, Japan National Institute of Occupational Safety and Health, \\ 6-21-1 Nagao, Tama-ku, Kawasaki 214-8585, Japan
}

(Received December 10, 2015; Accepted December 14, 2015)

\begin{abstract}
We examined the effect of methylmercury administration on expression of interleukin genes in brain of mice. We found that gene expression of IL-1 $\beta$ and IL-19 was increased in the brain after the administration of methylmercury.
\end{abstract}

Key words: Methylmercury, Brain, Interleukin, IL-1 $1 \beta$, IL-19

\section{INTRODUCTION}

Methylmercury, known as a causative agent of Minamata disease, is an environmental pollutant that causes serious central nervous system (CNS) injuries including sensory paralysis, speech disturbance, ataxia and visual field constriction (Castoldi et al., 2003; Yuan, 2012). In recent years, the impact of methylmercury intake on fetal brains has been an issue of concern, stemming from seafood consumption by pregnant women (Grandjean et al., 1997; Murata et al., 1999; Nyland et al., 2011). However, the onset mechanism for methylmercury toxicity and the defense mechanism of living organisms against methylmercury have been poorly understood.

We analyzed expression variation of gene clusters in the brain of mice treated with methylmercury, identifying 2 chemokines (CCL3 and CCL4) as genes whose expression is increased by methylmercury in the brain (Lee et al., 2012; Kim et al., 2013). Methylmercury has also been reported to induce the expression of interleukin IL-6, a kind of cytokine (Chang, 2007; Noguchi et al., 2013).

Cytokines are secretory proteins produced primarily by immune system cells. These proteins bind to certain receptors on the cell surface membrane to activate a specific signaling pathway and play important roles in the growth and differentiation of cells, induction of cell death, and inflammation and immunity (Guazzone et al.,
2009; Brocker et al., 2010). However, observations on the relationship between methylmercury and cytokines in the brain have not yet been reported. In this study, we focused on the interleukin family, a type of cytokines, and analyzed expression level variation of interleukin molecular species in the brain of mice treated with methylmercury.

\section{MATERIALS AND METHODS}

\section{Animal experiments}

Six-week-old male C57BL/6 mice were purchased from Japan SLC, Inc. (Shizuoka, Japan). The mice were housed in plastic cages ( 4 animals per cage) at $22 \pm 2{ }^{\circ} \mathrm{C}$ with a relative humidity of $55 \pm 20 \%$ under a 12 -hr lightdark cycle and allowed free access to chow (F-2, Oriental Yeast, Tokyo, Japan) and water. All experiments were performed in accordance with the Regulations for Animal Experiments and Related Activities at Tohoku University. After an adaptation period, mice were randomly divided into control $(n=5)$ and methylmercury-treated $(n=5)$ groups. Methylmercuric chloride dissolved in physiological saline was administered by subcutaneous injection.

\section{Measurement of interleukin mRNA levels by quantitative real-time PCR}

Tissues were homogenized, and total RNA was isolated using the Isogen Kit (Nippon Gene, Tokyo, Japan)

Correspondence: Akira Naganuma (E-mail: naganuma@m.tohoku.ac.jp) 
T. Takahashi et al.

according to the manufacturer's protocol. The first-strand cDNA was synthesized from $0.5 \mu \mathrm{g}$ of total RNA using the PrimeScript ${ }^{\mathrm{TM}}$ RT Reagent Kit (Takara, Shiga, Japan). Quantitative real-time PCR analysis was performed using SYBR Premix EX Taq (Takara) with Thermal Cycler Dice $^{\circledR}$ (Takara) (Takahashi et al., 2013). The oligonucleotide sequences of the primers used for qPCR are shown in Table 1.

\section{RESULTS AND DISCUSSION}

Methylmercuric chloride $(25 \mathrm{mg} / \mathrm{kg}$ ) was subcutaneously administered to C57BL/6 male mice in a single dose. After 5 days, brain (cerebellum and cerebrum) was resected to examine mRNA levels of genes coding 36 interleukins using quantitative PCR. In the cerebellum, significant increases in expression of genes for

Table 1. Oligonucleotide primers used for quantitative real-time PCR.

\begin{tabular}{|c|c|c|}
\hline Gene & Sense (5'-3') & Anti-sense (5'-3') \\
\hline IL- $1 \alpha$ & gcaacgggaagattctgaag & Tgacaaacttctgcctgacg \\
\hline IL-1 $\beta$ & geccatcctctgtgactcat & aggccacaggtattttgtcg \\
\hline IL-1Ra & ttgtgccaagtctggagatg & Gttgtgcagaggaaccatcc \\
\hline IL-2 & gcccaagcaggccacagaat & Gggettgttgagatgatgctttga \\
\hline IL-3 & cetgggactccaagcttcaa & Gacaatagagctgcaattcaacgt \\
\hline IL-4 & tcaacccccagctagttgtc & Tctgtggtgttcttcgttgc \\
\hline IL-5 & caccagctatgcattggaga & Gtctctcctcgecacacttc \\
\hline IL-6 & agttgccttcttgggactga & tccacgtttcccagagaac \\
\hline IL-7 & attgeccgaataatgaacca & Accagtgtttgtgtgecttg \\
\hline IL-8 & tccaattcgggagacctcta & Taggcatcactgcctgtcaa \\
\hline IL-9 & ctccgtcccaactgatgatt & Aaggacggacacgtgatgtt \\
\hline IL-10 & ccaagccttatcggaaatga & Ttttcacaggggagaaatcg \\
\hline IL-11 & ctcttcagaccctcgagcag & Aagctgcaaagatcccaatg \\
\hline IL-12 (p35) & catcgatgagctgatgcagt & cagatagcccatcaccetgt \\
\hline IL-12 (p40) & cacactggaccaaagggact & tggtttgatgatgtccetga \\
\hline IL-13 & cagcatggtatggagtgtgg & gtgggctacttcgattttgg \\
\hline IL-14 & aacctatgcagccaggaatg & ctccttccetagaccettgg \\
\hline IL-15 & gaggctggcattcatgtctt & gcaattggaggagaaagcag \\
\hline IL-16 & ctggcetaacacaccaggat & gagacgctggactttccaag \\
\hline IL-18 & ggctgccatgtcagaagact & gggttcactggcactttgat \\
\hline IL-19 & tggagaacctcaggagcatt & gaatgtcagcaggttgttgg \\
\hline IL-20 & attcgggatagtgtgcaagc & gtggtcaggggtctggtaga \\
\hline IL-21 & cgcetcctgattagacttcg & cagggtttgatggcttgagt \\
\hline IL-22 & caacttccagcagccataca & gttgagcacctgcttcatca \\
\hline IL-23 & aataatgtgeccegtatcca & ctggaggagttggctgagtc \\
\hline IL-24 & cactctggccaacaacttca & getttcaccaaagcgacttc \\
\hline IL-25 & gaggagtggctgaagtggag & catgtgggagcctgtctgta \\
\hline IL-27 (p28) & ctctgcttcctcgctaccac & aggggcagcttcttttcttc \\
\hline IL-27 (EBI3) & gtccaagctgctcttcctgt & gacgtggatctggtggagtt \\
\hline IL-28 & tacacagcttcaggccacag & tggccacacacttgaggtccc \\
\hline IL-31 & caggaacaacgaagcctacc & tgattcgtctgctgacatcc \\
\hline IL-33 & gctgcgtctgttgacacatt & gacttgcaggacagggagac \\
\hline IL-34 & ctgtgcettatgagggggta & cgttctccagcaatgtctga \\
\hline IL-36 $\alpha$ & cacgtacatgggagtgcaaa & gcagctccctttagagcaga \\
\hline IL-36 $\beta$ & ggctttccetccacaatctt & ttccagtcaggacccatacc \\
\hline 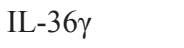 & cccatgcaagtacccagagt & gggaaagccactgattcaa \\
\hline GAPDH & atcaccatcttccaggagcga & aggggccatccacagtctt \\
\hline
\end{tabular}


Induction of IL-1 $\beta$ and IL-19 by methylmercury

\section{(A) Cerebellum}

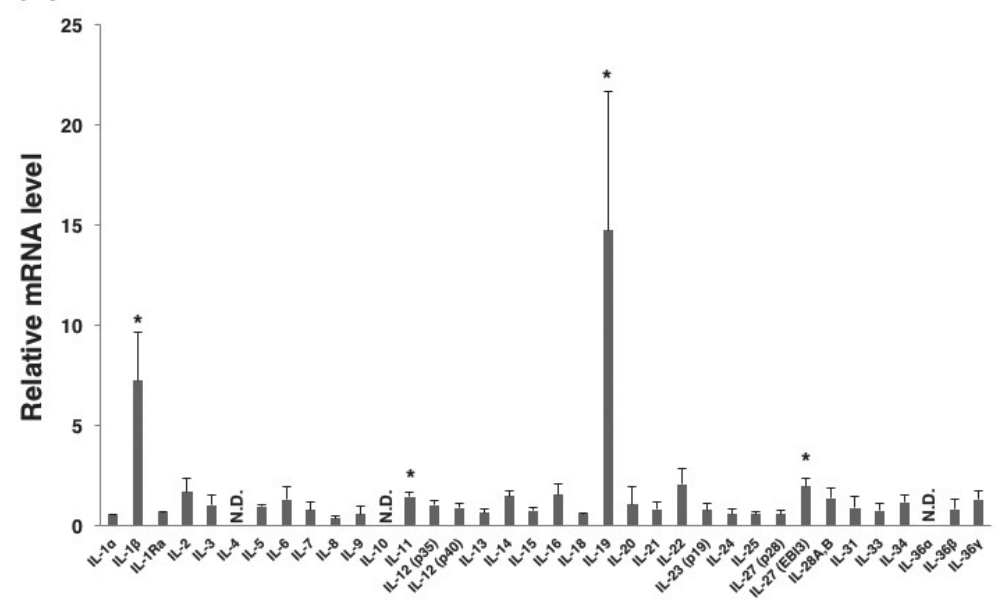

(B) Cerebrum

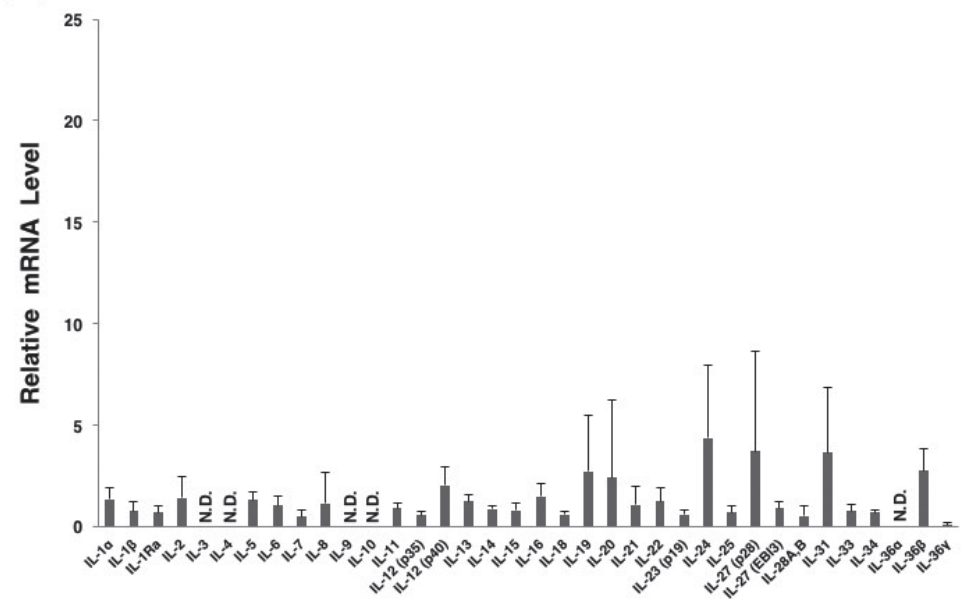

Fig. 1. Effect of methylmercury on the mRNA levels of interleukins in mice brain tissue. C57BL/6 mice were injected subcutaneously with methylmercuric chloride $(25 \mathrm{mg} / \mathrm{kg}$ /day). Selected tissues were dissected 5 days after injection. mRNA levels for 36 interleukins were measured by quantitative real-time PCR in the cerebellum (A) and cerebrum (B) in methylmercury-treated and control mice. mRNA levels were normalized to GAPDH levels. Data shows fold-changes in mRNA levels $($ mean \pm S.D.). * Significantly different from control group $(p<0.05)$. Data were analyzed using a Dunnet test.

IL-1 $\beta$ and IL-19 by the methylmercury administration were observed (Fig. 1A). On the other hand, methylmercury did not significantly increase the expression of any of the tested interleukin genes in the cerebrum (Fig. 1B).

Next, we examined changes in the expression level over time for IL-1 $\beta$ and IL-19 in each tissue of mice subcutaneously treated with methylmercury in a single dose (Fig. 2). As a result, for IL-1 $\beta$, increased expression was observed on Day 1 after administration in the cerebellum, as well as a significant expression increase in the kidney. For IL-19, increased expression was observed on Day 7 in the cerebrum, and after Day 5 in the cerebel- lum. Increased expression of IL-19 was also found in the kidney, but the degree of increase was lower than that in the brain. Therefore, IL-19 is considered to be a cytokine showing relatively brain-selective increased expression caused by methylmercury.

IL-1 $\beta$ is a proinflammatory cytokine (Neveu and Liege, 2000) and is known to have apoptosis inducing action (Grunnet et al., 2009; Vanderford, 2010). Therefore, we cannot deny the possibility that induced expression of these cytokines in the brain tissue is involved in methylmercury cytotoxicity in the CNS. Alternatively, as the cytotoxicity of IL-19 has been reported (Hsu et al., 


\section{(A) IL-1 $\beta$ mRNA level}
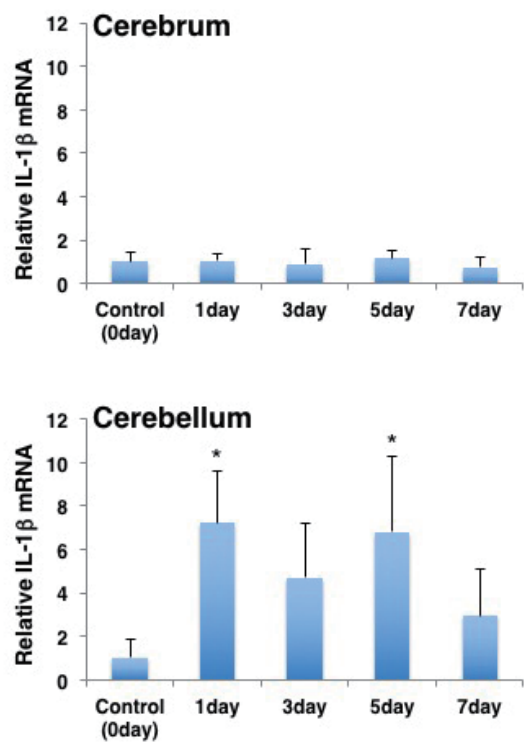

(B) IL-19 mRNA level
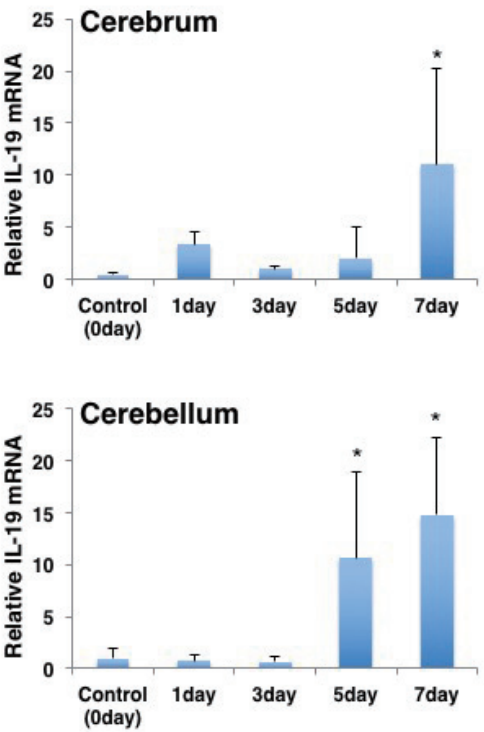
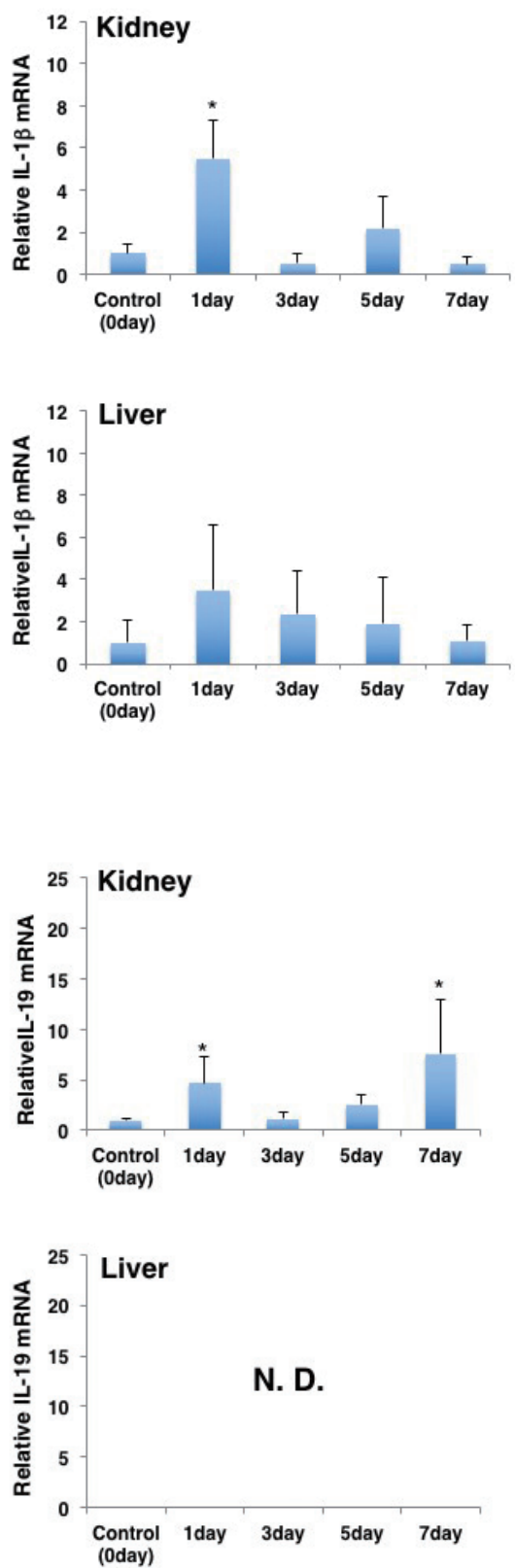

Fig. 2. Effect of methylmercury on mRNA levels of Il-1 $\beta$ and IL-19 in various mouse organs. C57BL/6 mice were injected subcutaneously with methylmercuric chloride $(25 \mathrm{mg} / \mathrm{kg})$. Selected tissues were dissected at 1 day, 3 days, 5 days and 7 days after injection. mRNA levels of Il-1 $\beta$ and IL-19 in the cerebellum, cerebrum, liver and kidney were measured by quantitative real-time PCR. For further details, see the legend to Fig. 1.

2013), the mechanism by which methylmercury induces brain-specific expression of IL-19 may also be associated with the mechanism for brain-selective onset of toxicity shown by methylmercury.
In the future, defining the relationship between these cytokines and methylmercury toxicity is expected to lead to clarification of the mechanism for CNS damage. 
Induction of IL-1 $\beta$ and IL-19 by methylmercury

Conflict of interest---- The authors declare that there is no conflict of interest.

\section{REFERENCES}

Brocker, C., Thompson, D., Matsumoto, A., Nebert, D.W. and Vasiliou, V. (2010): Evolutionary divergence and functions of the human interleukin (IL) gene family. Hum. Genomics, 5, 30-55.

Castoldi, A.F., Coccini, T. and Manzo, L. (2003): Neurotoxic and molecular effects of methylmercury in humans. Rev. Environ. Health, 18, 19-31.

Chang, J.Y. (2007): Methylmercury causes glial IL-6 release. Neurosci. Lett., 416, 217-220.

Grandjean, P., Weihe, P., White, R.F., Debes, F., Araki, S., Yokoyama, K., Murata, K., Sorensen, N., Dahl, R. and Jorgensen, P.J. (1997): Cognitive deficit in 7-year-old children with prenatal exposure to methylmercury. Neurotoxicol. Teratol., 19, 417-428.

Grunnet, L.G., Aikin, R., Tonnesen, M.F., Paraskevas, S., Blaabjerg, L., Storling, J., Rosenberg, L., Billestrup, N., Maysinger, D. and Mandrup-Poulsen, T. (2009): Proinflammatory cytokines activate the intrinsic apoptotic pathway in beta-cells. Diabetes, $\mathbf{5 8}$, 1807-1815.

Guazzone, V.A., Jacobo, P., Theas, M.S. and Lustig, L. (2009): Cytokines and chemokines in testicular inflammation: A brief review. Microsc. Res. Tech., 72, 620-628.

Hsu, Y.H., Li, H.H., Sung, J.M., Chen, W.T., Hou, Y.C. and Chang, M.S. (2013): Interleukin-19 mediates tissue damage in murine ischemic acute kidney injury. PLoS One, 8, e56028.

Kim, M.S., Takahashi, T., Lee, J.Y., Hwang, G.W. and Naganuma,
A. (2013): Global chemokine expression in methylmercurytreated mice: methylmercury induces brain-specific expression of CCL3 and CCL4. J. Toxicol. Sci., 38, 925-929.

Lee, J.Y., Hwang, G.W., Kim, M.S., Takahashi, T. and Naganuma, A. (2012): Methylmercury induces a brain-specific increase in chemokine CCL4 expression in mice. J. Toxicol. Sci., 37, 12791282.

Murata, K., Weihe, P., Araki, S., Budtz-Jorgensen, E. and Grandjean, P. (1999): Evoked potentials in Faroese children prenatally exposed to methylmercury. Neurotoxicol. Teratol., 21, 471-472.

Neveu, P.J. and Liege, S. (2000): Mechanisms of behavioral and neuroendocrine effects of interleukin-1 in mice. Ann. N.Y. Acad. Sci., 917, 175-185.

Noguchi, Y., Shinozaki, Y., Fujishita, K., Shibata, K., Imura, Y., Morizawa, Y., Gachet, C. and Koizumi, S. (2013): Astrocytes protect neurons against methylmercury via ATP/P2 $\mathrm{Y}_{1}$ receptormediated pathways in astrocytes. PLoS One, 8, e57898.

Nyland, J.F., Wang, S.B., Shirley, D.L., Santos, E.O., Ventura, A.M., de Souza, J.M. and Silbergeld, E.K. (2011): Fetal and maternal immune responses to methylmercury exposure: a cross-sectional study. Environ. Res., 111, 584-589.

Takahashi, T., Kim, M.S., Saito, T., Lee, J.Y., Hwang, G.W. and Naganuma, A. (2013): Brain-specific induction of secretoglobin $3 \mathrm{~A} 1$ expression in mice treated with methylmercury. J. Toxicol. Sci., 38, 963-965.

Vanderford, N.L. (2010): Defining the regulation of IL-1beta- and CHOP-mediated beta-cell apoptosis. Islets, 2, 334-336.

Yuan, Y. (2012): Methylmercury: a potential environmental risk factor contributing to epileptogenesis. Neurotoxicology, 33, 119126. 